\title{
PENGGUNAAN BAHASA LISAN DI PESISIR LAUT SELATAN
}

(Studi Deskriptif tentang Kedwibahasaan Para penutur di Kecamatan

Pangandaran, Kabupaten Ciamis)

D. Syahruddin

\begin{abstract}
Abstrak
Manusia sebagai makhluk sosial menggunakan bahasa sebagai salah satu alat komunikasi. Bahasa merupakan salah satu sarana komunikasi yang sangat vital bagi kehidupan manusia. Manusia dapat mengungkapkan pikiran dan perasaannya melalui bahasa. Tanpa adanya bahasa manusia tidak akan bisa berkomunikasi secara sempurna, meski pun ada sarana komunikasi yang lain selain bahasa. Penelitian ini bertujuan untuk memperoleh gambaran umum tentang penggunaan bahasa lisan di pesisir laut selatan, khususnya para penutur di Kecamatan Pangandaran Kabupaten Ciamis.

Hasil dari penelitian ini adalah 1) adanya penggunaan bahasa (undak-usuk basa) yang digunakan murid sekolah dasar di wilayah Kecamatan Pangandaran, Kabupaten Ciamis, lebih disebabkan oleh perbedaan umur, bukan berdasarkan kelas sosial masyarakat baik kaya atau miskin, terpelajar atau cacah; 2) Etnisitas orang tua tidak berpengaruh pada penggunaan etika berbahasa Sunda; 3) para pedagang dan nelayan di pantai Pangandaran umumnya sudah mengenal penggunaan etika berbahasa Sunda ( undak-usuk basa), meski pun mereka berasal dari daerah lain (misalnya Jawa).
\end{abstract}

\section{Kata kunci : bahasa lisan, para penutur, pesisir laut selatan}

\section{A. PENDAHULUAN}

Bahasa merupakan salah satu alat komunikasi yang digunakan manusia untuk mencurahkan isi hati, pikiran, perasaan, keinginan, emosi dan lain-lain, baik untuk dirinya sendiri maupun orang lain. Tanpa adanya bahasa manusia tidak akan dapat berkomunikasi dengan baik. Sebagaimana dikatakan oleh Suhendar et al (1997/1998 : 3), bahwa manusia mempergunakan bahasa sebagai sarana komunikasi vital dalam hidup. Bahasa adalah milik manusia. Bahasa mempunyai fungsi yang amat penting bagi manusia. Fungsi bahasa adalah instrumental, regulasi, representasional, personal, heuristik, interaksioanal, dan imajinatif. Bahasa sebagai aspek kebudayaan, bahasa dan aspek-aspek lain dari kebudayaan, sebagai pendukung kebudayaan, atau kebudayaan sebagai pendukung bahasa, dan bahasa sebagai cermin kebudayaan, merupakan ungkapan-ungkapan yang 
tercermin di masyarakat yang menggambarkan hubungan bahasa dengan kebudayaan. Halim (1980 : 37), mengatakan bahwa bahasa yang mengonsepsikan seluruh isi alam pikiran manusia dalam lambang-lambang yang berwujud nyata merupakan sokoguru dalam tiap kebudayaan.

Menurut Alwasilah (1986 : 7), hanya manusialah yang memiliki sistem simbol untuk berkomunikasi. Betul bahwa hewan lain seperti binatang pun berkominikasi, dan mempunyai sistem bunyi, tetapi sistem itu bukanlah kata-kata. Dengan demikian mereka tidak memiliki bahasa. Manusia telah berbahasa sejak dini sejarahnya, dan perkembangan bahasanya inilah yang membedakan manusia dari makhluk lain, hinggga membuat dirinya mampu berpikir. Selanjutnya Suhendar et al (1997/1998 : 5) mengatakan, bahwa bahasa merupakan alat komunikasi utama, dan dengan bahasa manusia mengungkapkan pikiran dan perasaannya kepada orang lain. Proses-proses pemikiran sangat ditentukan oleh kemampuan berbahasa. Melalui ungkapan bahasa, pikiran, perasaan, dan penalaran seseorang dapat dirangsang dan dilatih. Kemampuan menggunakan bahasalah yang paling membedakan nanusia dari makhluk hidup lainnya. Bahasa memungkinkan manusia untuk menyampaikan informasi dan meneruskannya dari genarasi ke generasi, melalui ungkapan secara tertulis. Bahasa memungkinkan manusia untuk membangun kebudayaan serta menguasai ilmu pengetahuan, dengan demikian bahasa dapat meningkatkan mutu kehidupannya. Bahasa juga dapat mempengaruhi arah perilaku manusia. Akhirnya dapat dikatakan bahwa bahasa memberikan manusia identitasnya, untuk menentukan posisinya di dalam dunia dan membentuk pandangannya tentang dunianya. Di samping itu pula Tarigan (1994 : 1), mengatakan bahwa bahasa seseorang mencerminkan pikirannya. Semakin trampil seseorang berbahasa, semakin cerah dan jelas pula jalan pikirannya. Dengan menyimak penjelasan di atas maka jelaslah, bahwa bahasa merupakan alat komunikasi yang sangat vital bagi kehidupan manusia sebagai makhluk sosial.

Sehubungan dengan latar belakang di atas, yang menjadi permasalahan dalam penelitian ini adalah bagaimana variasi penggunaan bahasa lisan para penutur yang berbeda usia, pendidikan dan latar belakang sosial. Permasalah ini dapat dijabarkan ke dalam rumusan masalah penelitian sebagai berikut.

1. Bagaimana pemakaian variasi berbahasa bagi para penutur berdasarkan faktor usianya (anak-anak, remaja, dewasa, dan orang tua)?

2. Bagaimana pemakaian variasi berbahasa di antara para penutur yang berbeda latar belakang pekerjaannya?

3. Bagaimana pemakaian variasi berbahasa di antara para penutur yang berbeda latar belakang status sosialnya? 
Sejalan dengan perumusan masalah di atas, penelitian ini dilaksanakan bertujuan untuk memperoleh gambaran umum tentang penggunaan bahasa lisan di pesisir laut selatan, khususnya para penutur yang berdomosili di Kecamatan Pangandaran Kabupaten Ciamis. Secara khusus tujuan yang ingin dicapai dalam penelitian ini sebagai berikut.

1. Mendapatkan gambaran seberapa jauh penggunaan variasi berbahasa lisan berdasarkan usianya (anak usia SD, anak usia SMP, dan anak usia SMA);

2. Mendapatkan gambaran seberapa jauh penggunaan variasi berbahasa lisan di antara para penutur yang berbeda latar belakang pekerjaannya;

3. Mendapatkan gambaran seberapa jauh penggunaan variasi berbahasa lisan para penutur yang berbeda latar belakanag sosialnya.

Manfaat yang diharapkan dapat diperoleh, baik secara langsung maupun tidak langsung dari penelitian ini adalah :

1. memberikan informasi yang positif bagi para pakar bahasa tentang bahasa lisan yang dipergunakan masyarakat yang berdomisili di pesisir laut selatan, khususnya di pantai Pangandaran;

2. diharapkan dapat memberikan pengalaman berharga bagi peneliti yang sedang menekuni bahasa, dan sebagai dosen pengampu mata kuliah rumpun bahasaUniversitas Pendidikan Indonesia; dan

3. diharapkan dapat memberikan sumbangan bagi para pakar bahasa dalam mengkaji ilmu bahasa, khususnya ilmu bahasa yang berhubungan dengan kedwibahasaan (bilingualisme)

\section{B. LANDASAN TEORETIS}

Sebagaimana kita ketahui bahwa penduduk Indonesia yang mendiami kepulauan Nusantara yang terdiri atas berbagai suku Bangsa, sudah barang tentu memiliki sosial budaya, adat istiadat, dan bahasa yang berbeda. Masyarakat Indonesia yang majemuk yang terdiri atas 300 golongan etnik dengan identitas nilai budaya masing-masing ditambah dengan aneka bahasa daerah sejumlah 250 ragam (Warsito, 1984 : 145).

Dengan keanekaragaman suku Bangsa ini tentunya masyarakat Indonesia di dalam kehidupan sehari-harinya menggunakan bahasa Daerah sebagai alat komunikasi di dalam lingkungannya sendiri, baik itu secara lisan maupun secara tertulis. Berdasarkan data dari Biro Pusat Statistik tahun 1983, yang disalin oleh Emil Salim ( 1983), dalam Suhendar et al (1997/1998 : 167), sebanyak 40 \% (59,4 juta) masyarakat Indonesia menggunakan bahasa Jawa di dalam pergaulan sehari-hari. Disusul dengan bahasa Sunda, sebanyak 15 \% (22,1 juta), dan bahasa Madura sebanyak 5 \% (6,9 juta), bahasa Minang sebanyak $2 \%$ 
(3,5 juta), bahasa Bugis $2 \%$ (3,3 juta), bahasa Batak $2 \%$ (3,1 juta), bahasa Bali 2 \% (2,5 juta), bahasa Banjar $1 \%$ (1,7 juta), serta lain-lain bahasa $19 \%$ (26,7juta).

Dalam berkomunikasi itu bisa berjalan dengan baik, apabila si penutur mengetahui dan memahami faktor-faktor penentu dalam komunikasi. Faktor-faktor tersebut terdiri atas tujuh hal, yaitu :

1. siapa yang berbahasa dengan siapa;

2. untuk tujuan apa;

3. dalam konteks apa (peserta lain, kebudayaan, dan suasana);

4. dalam situasi apa (tempat dan waktu)

5. dengan jalur mana (lisan atau tulisan );

6. media apa (tatap muka, telepon, surat, kawat, buku, Koran, dan sebagainya); dan

7. dalam peristiwa apa (bercakap-cakap, ceramah, upacara, laporan, lamaran kerja, menyatakan cinta, dan sebagainya) (Tarigan et al, 1990 : 311-312 ; Yudibrata et al, 1990 : 36)

Di samping itu pula Nababan (tarigan et al, 1990 ; 312) menyatakan, bahwa bahasa mempunyai bentuk dan makna. Bentuk dan makna bahasa disesuaikan dengan konteks dan situasi atau keadaan. Situasi dan konteks yang berbeda menyebabkan ragam bahasa yang berbeda pula. Keragaman bahasa ditentukan oleh faktor yang berakar dari konteks dan situasi seperti letak geografis, situasi berbahasa, status sosial, dan kurun waktu. Kita kenal empat ragam bahasa, yakni :

1. ragam daerah atau dialek;

2. ragam sosial atau sosiolek;

3. ragam fungsional atau fungsiolek; dan

4. ragam temporal atau kronolek.

Ragam bahasa yang berkaitan dengan letak geografis adalah ragam daerah atau dialek, sedangkan ragam yang berkaitan dengan status sosial adalah ragam sosial atau sosiolek. Dalam penelitian yang kami laksanakan ini tertmasuk ke dalam ragam geografis dan ragam sosial karena tempat penelitiannya berlokasi di pesisir laut selatan, dan para respondennya terdiri atas para pedagang, nelayan, buruh, petani (jenis pekerjaan), anak-anak, remaja, dewasa, dan orang tua (faktor usia)

Dalam kaitannya dengan etika berbahasa, mari kita ambil contoh faktor penentu berkomunikasi, siapa yang berbahasa dengan siapa. Kemungkinan pertama, pembicara setaraf, sejajar, atau sama kedudukannya dengan lawannya berbicara. Dalam keadaan seperti ini pembicara memliki kebebasan dalam 
memilih dan menggunakan kata ganti seperti saya, aku, kamu, dan sebagainya. Kemungkinan kedua, pembicara lebih rendah dari lawan bicaranya. Misalnya, percakapan atau dialog antara anak dengan orang tua, siswa dengan guru, pesuruh dengan kepala bagian dan sebaliknya. Dalam keadaan seperti ini pembicara harus dapat memilih dan dapat menggunakan bahasa yang tepat. Pembicara tentu kurang pantas bila menggunakan kata ganti aku, daku, atau engkau, kamu. Kemungkinan ketiga, kedudukan penbicara lebih tinggi dari kedudukan lawan bicaranya. Misalnya percakapan atau dialog antara ibu dengan anaknya, guru dengan siswa, pimpinan dengan stafnya, dan sebagainya. Dalam keadaan seperti ini pembicara memilih dan menggunakan kata ganti seperti Bapak, Ibu, aku, daku, engkau, kamu, dan sebagainya (Tarigan et al, 1990 : 313).

Dalam bahasa Sunda etika berbahasa itu lebih lazim dikenal dengan undak- usuk basa. Menurut Yudibrata et al (1990 : 46 - 47), Undak usuk mangrupa sistem digunakeunana ragam hormat jeung ragam loma anu raket patalina jeng kalungguhan (status) relatif, kakawasaan (power) jeung dalit henteuna antara anu nyarita, batur nyarita, jeung jalma nu dicaritakeun.

\section{METODE PENELITIAN}

Penelitian ini merupakan survai lapangan untuk mendapatkan gambaran tentang kedwibahasaan para penutur di Kecamatan Pangandaran, maka metode yang digunakan adalah metode deskriptif. Instrumen penelitian yang digunakan untuk memperoleh data pemakaian variasi berbahasa para penutur di Kecamatan Pangandaran di antaranya alat perekam dan pedoman wawancara.

Untuk memperoleh data yang akurat dalam penelitian ini dilakukan hal-hal sebagai berikut.

1. Persiapan

a. Membuat instrumen penelitian;

b. validasi instrumen pengukurannya dilakukan oleh teman sejawat; dan

c. menetapkan subjek penelitian, termasuk sampel yang akan diteliti.

\section{Pelaksanaan}

Pengumpulan data dilaksanakan di lokasi penelitian yaitu sekitar pantai yang masuk ke dalam wilayah Kecamatan Pangandaran, Kabupaten Ciamis. Objek Penelitian adalah anak usia sekolah dasar, anak usia sekolah menengah pertama, anak usia sekolah menengah umum yang berada di Wilayah Kecamatan Pangandaran, Kabupaten Ciamis. 


\section{HASIL PENELITIAN}

\section{Variasi Pemakain Etika Berbasa Anak Usia Sekolah Dasar}

Di bawah ini akan dirinci beberapa contoh pemakain undak-usuk basa Sunda, terutama yang biasa digunakan anak-anak tingkat sekolah dasar. Contohcontoh ini dikelompokkan berdasarkan lingkungan di mana anak itu berada dan kepada yang diajak bicara oleh anak itu. Jadi di bawah ini hanya menagambil contoh-contoh secara umum, masalah gender tidak akan dipersoalkan.

\section{a. Undak-Usuk Basa Berdasarkan Lingkungan}

1) Bahasa Sunda Anak Sekolah Dasar di Lingkungan Tempat Bermain

Kalau di tempat bermain, bahasa yang digunakan oleh anak-anak umpamanya :

a) “Urang ngiluan euy!” kata salaserang anak kayang sedang bermain kelereng.

b) “Naon maneh mah licik!” kata anak yang dicurangi.

c) “Awas bagean urangeun!” kata anak yang kegiliran melemparkan kelereng.

d) “Maneh rek milu moal maen langlayangan?” kata si A ka si B.

e) "Urang nginjeum sapedah nu maneh euy!"

Kata-kata yang tercetak miring, tergolong kepada bahasa Sunda loma (kasar). Kata urang bahasa halusnya abdi; kata ngiluan bahasa halusnya ngiringan; kata maneh halusnya salira (bisa juga menyebut anjeun atau langsung menyebut nama), kata rek bahasa halusnya bade; kata nginjeum bahasa halusnya nambut.

2) Bahasa Sunda Anak Sekolah Dasar di Sekolah.

a) “Hilap, Pa!” kata salah seorang anak yang ditanya guru karena tidak membuat PR.

b) “Nina atos ngerjakeun PR Matematika?” kata Tita ketika sedang berada dikelas.

c) “Atos sapalih”. Jawab Nina.

d) “Ari Tita atos?” Nina berbalik bertanya.

e) “Abi mah teu tiasa nomer dalapan.” kataTita.

Kata-kata yang tercetak miring termasuk bahasa halus, Kata hilap kasarnya poho, kata atos bahasa kasarnya geus, kata sapalih kasarnya sawaereh, kata abdi basa kasarnya urang, kata tiasa bahasa kasarnya bisa.

3) Bahasa Sunda Anak-anak SD di Lingkungan Keluarga

a) “Atos!' kata salah seorang anak ketika ditanya ibunya apakah sudah makan atau belum. 
b) “Mah ngiring!” kata Tita kepada ibunya ketika mau berangkat ke sawah.

c) “Ua, gening Agus teu ngiring?” kata Tita menanyakan Agus kepada uanya ketika berkunjung ke rumahnya.

d) “Teu aya ditambut ku Dadi.” Kata Dadan ketika Uanya bertanya tentang speda miliknya.

e) “Moal ah ayeuna mah, enjing wae.” Jawab Tita ketika Uanya bertanya apakah mau ikut atau tidak kerumahnya

Kata-kata yang tercetak miring termasuk bahasa halus. Kecap atos bahasa kasarnya enggeus, kata ngiring basa kasarnya ngilu, kata ditambut basa kasarya diinjeum, kata enjing basa kasarnya isukan.

4) Bahasa Sunda Anak-anak di Lingkungan Madrasah atau di Masjid

a) “Teu acan tiasa surat An-Nas mah, pami Al-Ihlas mah tiasa." Kata Tita waktu Nina menanyakan hafal atau tidaknya Tita surat An-Nas.

b) “Teu aya Pa, Nina mah udur saur Mamahna mah.” Kata Tita sewaktu Pa Ustad menanyakan Nina.

c) “Pa, saur pun bapa, Bapa kedah ka bumi.” Kata Tita kepada Pak Ustad.

Kata-kata yang tercetak miring termasuk bahasa Sunda halus. Kata teu acan bahasa kasarnya acan, kata tiasa bahasa kasarnya bisa, kata pami (upami) bahasa kasarnya lamun, kata teu aya basa kasarnya euweuh, kata udur bahasa kasarnya gering, kata saur bahasa kasarnya ceuk, kata kedah bahasa kasarnya kudu, kata bumi bahasa kasarnya imah (meskipun pemakaian dalam kalimat salah penempatannya - seharusnya untuk diri sendiri rorompok).

\section{b. Undak usuk basa berdasarkan lawan bicara.}

Tingkatan bahasa yang digunakan berdasarkan kepada yang diajak bicara tidak jauh berbeda dengan apa yang telah diutarakan di atas. Lingkungan, sebenarnya ikut menentukan dengan siapa anak itu berbicara. Misalnya saja kalau anak itu berada di tempat bermain, tentu lawan bicaranya itu dengan teman seusianya. Dengan demikian, tentu bahasa yang digunakannya juga bahasa kasar (loma). tetapi kalau lawan bicaranya orang tua, meskipun berada di lingkungan tempat bermain, tentu bahasa Sunda yang digunakannya yaitu bahasa Sunda halus. Begitu pula sebaliknya, meskipun sedang berada di rumah, di sekolah, atau di masjis, seandainya lawan bicara teman sebaya, tentu bahasa yang digunakannya itu bahasa kasar. 


\section{Penggunaan Etika Bahasa Sunda Usia Remaja (SLTP)}

Penggunaan etika bahasa Sunda berdasarkan data yang terkumpul dari usia remaja SLTPN I Pangandaran ada dua macam yaitu ragam bahasa loma dan ragam bahasal

hormat (lemes/ halus).

1) Ragam loma

Ragam loma dapat juga dikatakan bahasa sunda umum; yaitu bahasa sunda yang tanpa basa-basi (tetapi juga tanpa pemakaian kata-kata yang menghina). Ragam loma digunakan apabila berbicara dengan orang yang sudah akrab dan membicarakan orang yang sudah akrab.

Contoh dari data yang terkumpul :

a) Kuring mah can mandi

b) Urang balik yu!

c) Ayeuna usum ngadu langlayangan

2) Ragam hormat (lemes/halus)

Ragam hormat dibagi dua yaitu

a) Ragam hormat (lemes/halus) Untuk persona I, yaitu bahasa lemes/halus yang digunakan pembicara atau orang lain yang sederajat.

Contoh : (1). Mah, mios ka sakola

(2). Punten, abdi ngiring ngalangkung

(3). Pa, rerencangan teu tiasa kasakola, udur

(4). Mah, abdi nyuhunkeun artos

(5). Mah, punten hoyong neda

b) Ragam hormat untuk persona II yaitu, ragam hormat (lemes/halus) yang digunakan untuk orang yang diajak bicara (lawan bicara), juga digunakan untuk orang yang sederajat dengan persona II yang status sosialnya, usia lebih tinggi dari pembicara.

Contoh : $\quad$ (a) Mah, punten pangnyandakeun patlot.

(b) Bapa guru nuju ngawulang.

(c) Bapa camat oge resepeun ngaben langlayangan.

Dari hasil temuan wawancara / rekaman, penggunaan ragam hormat (lemes/halus) ada yang sesuai dengan kaidah-kaidah (norma-norma) baku yang berlaku dalam masyarakat berbahasa Sunda, dan kebanyakan menyimpang dari kaidah-kaidah tersebut. Penyimpangan-penyimpangan itu berupa kesalahan penggunaan ragam hormat untuk persona I tertukar dengan ragam hormat untuk persona II atau sebaliknya. Selai daripada itu ada juga penggunaan bahasa kanakkanak (lemes budak) yang biasa digunakan di keluarga. 
(a) Penggunaan ragam hormat yang sesuai dengan kaidah-kaidah buku (undak usuk basa Sunda).

(1). Mah, mios ka sakola!

(2). Punten abdi ngiring ngalangkung.

(3). Pa, rerencanga teu tiasa kasakola udur.

(4). Mah, abdi nyuhunkeun artos.

(9). Mah, punten hoyong neda.

(6). Aa, pangnyandakeun pulpen!

(7). Bapa guru nuju ngawulang.

(b) Penggunaan ragam hormat untuk persona I tertukar dengan ragam hormat untuk pesrsona II atau sebaliknya.

(1). Bapa rerencangan teu damang, seharusnya Bapa rerencangan udur.

(2). Mah, bade angkat kasakola seharusnya Mah, bade mios ka sakola.

(3). Pa, Yuli teu tiasa ka sakola kumargi teu damang. Seharusnya Pa, Yuli teu tiasa dongkap margi udur.

(4). Rerencangan tos mulih. Seharusnya Rerencangan tos wangsul.

(5). Pa, punten pun bapa teu tiasa sumping margi teu damang. Seharusnya $P a$, punten pun bapa teu tiasa dongkap margi udur. (yang dibicarakan status sosialnya lebih rendah dari pada yang diajak bicara, dianggap sederajat dengan pembicara).

(6). Bapa Camat oge resep ngaben langlayangan.

(c) Penggunaan ragam bahasa hormat kanak-kanak (keluarga) disebut juga lemes budak, yang tidak pantas digunakan usia remaja,/ orang dewasa.

Contoh : (1). Mah, hoyong emam ! seharusnya

Mah, hoyong neda!

(2). Mah, hoyong eueut! seharusnya

Mah, hoyong nginum!

(3). Hayu urang Uih! seharusnya

Hayu urang wangsul!

(4). Ma, ukeun cicis/acis! Seharusnya

Ma, nyuhunkeun artos.

(5). Mah, hoyong panggaleuhkeun acuk. seharusnya

Mah, mah hoyong panggaleuhkeun baju.

\section{Penggunaan Etika Bahasa Sunda di Kalangan Remaja (SLTA)}

a. Informan 1

1) Pendatang

2) +9 th 
3) Pensiunan janda

4) Bapak : Jawa (alm)

5) Ibu : Sunda

6) 6 orang

7) Bahasa Sunda ( kadang-kadang Jawa)

8) kadang-kadang

9) Teh ! pangnyandakeun sapu !

10) Ma ! abdi hoyong neda !

11) - Teu kadangueun panginten ku ramana

a. Bapa guru ngawulang

b. Abdi mah teu acan ibak

c. Urang balik yu!

12) $\mathrm{Pa}$ ! nyuhunkeeun dihapunten wireh pun rama teu tiasa sumping dina acara di sakola, kumargi salirana rada teu raraos. Mugi Bapa ngamalum.

13) Sanda teu tiasa dongkap ka sakola lantaran teu damang, $\mathrm{Pa}$ !

14) A, Punten ! ( badan, setengah dibungkukkan dengan kepala dianggukkan, tanpa

15) mengalihkan pandangan dari orang yang dilalui, kalau bisa berikanlah senyum.

16) - Ayeuna keur usum langlayangan.

a. Bapa Camat oge resep ngadu langlayangan

b. Informan 2

1) Asli Pangandaran

2) Sejak lahir ( th 1986)

3) Pengusaha hotel

4) Bapa : Sunda

Ibu : Sunda

5) tiga orang

6) Bahasa Sunda

7) Pernah

Bu ! Punten pangnyandakkeun itu !

8) Diberi

9) Mah ! Abdi hoyong tuang !

10) Bapa guru keur ngajar

- Kuring mah can mandi

- Urang balik, yu!

11) Pa! Punten pun Bapa teu tiasa sumping da nuju teu damang!

12) Sanda teu tiasa dongkap ka sakola, lantaran teu damang, $\mathrm{Pa}$ ! 


\section{3) A, Punten! ( membungkukkan kepala)}

14) Pernah

- Ayeuna usum ngadu langlayangan

- Bapa Camat oge resepeun ngadu langlayangan

c. Informan 3

1) Asli Pangandaran

2) Sejak lahir ( th 1985)

3) Buruh

4) Bapa : Sunda

Ibu : Sunda

5) Empat orang

6) Bahasa Sunda

7) Pernah !

- Mah ! Punten pangnyandakkeun anduk !

8) Selalu diberi

9) Mah abdi hoyong tuang !

10) Urang balik, yu !

11) Maaf $\mathrm{Pa}$ ! ayah saya tidak bisa hadir, karena sakit.

12) Maaf Pa ! Teman saya yang bernama Uci, tidak bisa hadir, karena sakit.

13) Punten! Ngiring ngalangkung ( sambil membungkukkan badan )

14) Belum pernah

d. Informan 4

1) Asli Pangadaran

2) Sejak lahir (1985)

3) Pekerjaan ayah : Petani

Pekerjaan ibu : petani

4) Bapa : Sunda

Ibu : Sunda

5) lima orang

6) Kadang-kadang

7) Pernah

Dengan Bahasa Jawa

8) Ya. ( minta)

9) Mah! Aku lapar

10) Aku mah urang adus

11) Pa ! punten Bapa abdi teu bisa datang sabab keur nyeri sirah!

12) Pak, hari ini teman saya tidak bisa datang ke sekolah karena sakit.

13) Punten! ( membungkukkan badan sedikit ) 
14) Pernah

- Ayeuna usum ngadu langlayangan.

- Bapa Camat juga suka bermain layang-layang.

e. Informan 5

1) Penduduk asli Pangandaran

2) Sudah lama ( sejak th 1985 / lahir )

3) Wiraswasta

4) Bapa : Sunda

Ibu : Sunda

5) empat orang

6) Bahasa sunda

7) Pernah

- Mah, Tolong ambilkan handuk!

8) Sering

9) $\mathrm{Bu}$ ! Saya lapar mau makan !

10) - Bapa guru keur ngajar.

- Kuring mah can mandi.

- Urang balik yu!

11) Maaf Pak ! Ayah saya tidak bisa hadir, badan lagi sakit.

12) $\mathrm{Bu}$, hari ini si Anu lagi sakit tipes permisi tidak bisa sekolah.

13) Permisi Pa ! ( sambil membungkukkan badan )

14) Pernah !

- Ayeuna usum ngadu langlayangan

- Bapa Camat oge resepeun ngadu langlayangan

\section{Penggunaan Etika Berbahasa Para Nelayan di Pantai Pangandaran}

a. Nelayan 1

1) "Dari kecil tinggal di sini”.

2) "Suami asal Cirebon, istri dari Tegal".

3) "Di rumahnya pake Bahasa Jawa tapi kalau di lingkungannya campur bae Jawa sama Sunda”.

4) "Penghasilannya tidak tentu, tergantung musimnya bae".

5) "Kalau ada burung tangkok, tanda di tempat itu ada ikannya”.

6) "Anak dua masih kecil-kecil sekolah di SD, ngomongnya di rumah Jawa di sama Sunda".

b. Nelayan 2

1) "Penduduk asli Sunda”.

2) “Suami dan Istri dari Pangandaran”. 
3) "Penghasilan teu tangtos, tergantung musiman bae, musim hujan mah nu kaluar bawal putih, musim kemarau anu seueur udang”.

4) “Angkat ti bumi subuh mulihna sonten".

5) "Hasil tangkapan upami seueur ka TPI dulu, nembe ka Bandar ageng”.

6) “Tapi upami sakedik diical ku nyalira bae”.

7) “Upami nuju aya angin timur sok aya badai”.

8) "Udang mah nyimpen, ngajaringna sonten tabuh opat, siang nembe ditarik”.

9) "Bangun tidur, tergantung tidurnya, kalau melaut subuh, pulang sore”.

c. Nelayan 3

1) "Suami dari Jawa istri dari Plores".

2) "Bahasa yang dipakai di rumah bahasa Indonesia”.

3) "Lingkunganna, bahasa Sunda campur Indonesia dan Jawa”.

4) "Penghasilan tidak tentu tergantung musim".

5) “Alat yang dipakai tergantung ikan yang sedang musim”.

6) “Jaring, untuk tenggiri dan bawal, pergi sore pulang subuh”.

7) "Jaring yang ditanam, untuk tangkap udang. Sore ditanam, tidak ditunggu, besok siang langsung ditarik”.

8) “Anak satu orang, masih kecil baru 8 tahun”.

9) "Makan 2 X sehari”.

10) "Jarak dari rumah ke Pantai istirahat karena 3 km”.

11) "Kalau di rumah, istirahat karena capek melaut”.

d. Nelayan 4

1) "Dibesarkan di Pangandaran asli Jawa (Kebumen) dan istri Sunda”.

2) "Bahasa yang dipakai ya campur bae”.

3) "Punya anak 2 orang”.

4) "Penghasilan teu tentu".

5) “Malam Jum' at tidak melaut dan hari Jum'at tidak ada lelang ikan”.

6) "Pergi kerja tergantung ikan yang ditangkap”.

7) “Kalau pergi sore pulang subuh”.

8) “Alat yang digunakan tergantung jenis ikan yang ditangkap”.

e. Nelayan 5

1) "Saya mah asli urang dieu ti Pangandaran."

2) "Gaduh anak toh dua urang."

3) "Penghasilan teu tangtos."

4) "Upami angkatna sonten, uihna subuh."

5) “Ti bumi kadieu jarakna aya 3 km.”

6) "Alat nu dicandak tergantung musim ikan naon anu nuju ka luar." 
7) "Upami ayeuna musim layur janten nganggo jaring, angkat sonten uih subuh."

8) "Bahasa nu dianggo Bahasa Pangandaran Sunda campur tea."

9) “ Ragragkeun bae jaringna.”

10) "Ieu jaring tilas dianggo."

11) "Bade persiapan deui angkat subuh."

12) “Dinten Jumat teu jadi ngalaut tos jadi kabiasaan.”

\section{Penggunaan Etika Berbahasa Para Pedagang di Pantai Pangandaran}

a. Pedagang Asin Asongan

1) "Penduduk asli Pangandaran desa prapatan.”

2) "Bahasa yang digunakan Bahasa Sunda campur Jawa.”

3) "Jumlah keluarga, anak 4 orang."

4) “Abdi mah sakolana dugi ka SD.”

5) “Teu ditangtoskeun kadang laris, kadang henteu, tergantung musiman bae."

6) "Sareng turis mah nganggo serat bae."

7) "Ti enjing-enjing nugi katabuh dua belas."

8) "Upami suami angkatna subuh uwihna sonten tabuh genep.”

9) “Caket di prapatan, caket di terminal."

10) "Rekreasi jarang."

11) “Upami atos di bumi nya istirahat bae." (Suami).

b. Pedagang Pakaian

1) "Upami asli mah ti kebumen."

2) "Lahir di dieu asli Pangandaran desa Babakan."

3) "Istri mah urang sunda."

4) "Di bumi nganggo bahasa Jawa istri nganggo bahasa Jawa."

5) "Upami di masyarakat mah nganggo bahasa Sunda bae."

6) "Penghasilan tidak tetap, ya tergantung musim libur atau tidak."

7) "Yah rekreasi kadang bae."

c. Pedagang Asin di Pantai

1) "Suami dari Jawa istri Sunda".

2) "Bahasa campur bae, Jawa sareng Sunda”.

3) "Gaduh putra teh opat, dua istri dua pameget".

4) "Upami nyarios sareng turis, nyarios bae sareng gaedna".

5) "Jarakna ti bumi aya 5 kilo, nganggo sapedah bae kadieu mah”.

6) "Suami mah tina bangunan didamelna".

d. Pedagang Asin di Kios

1) "Penduduk asli Pangandaran” 
2) "Abdi mah penduduk asli, nuju alit keneh di tempat ieu leuweung keneh, ayeuna mah tos rame".

3) “Teu tangtos ayeuna mah hese pajengna, nuju hese”.

4) "Asin jambal anu sae anu muruhuy".

5) “Enjing dinten Sabtu rame”.

6) “Jambal anu sae mah disimpen dina peti, supados seungitna henteu hiber”.

7) “Pangaosna anu sae langkung awis”.

e. Pedagang Pecel

1) “Asli Jawa Kebumen.

2) "Lahir di kampung Kulon Pangandaran".

3) "Suami kerjane nyadap kalapa".

4) "Bahasa di sekolah bahasa Jawa bae".

5) "Penghasilan lumayan bae daripada nganggur".

6) “Kelompok kampungne orang Jawa kabeh”.

\section{E. KESIMPULAN}

1. Adanya tingkatan penggunaan bahasa (undak-usuk basa) yang digunakan murid sekolah dasar di wilayah Kecamatan Pangandaran, Kabupaten Ciamis, lebih disebabkan adanya perbedaan umur, bukan berdasarkan kelas sosial kaya atau miskin, terpelajar atau cacah. Begitu pula di lingkungan sekolah atau masjid tidak menjadi halangan untuk berbicara kasar apabila diajak bicara oleh teman sebayanya. Lingkungan tempat bermain juga tidak menjadi halangan bagi anak-anak berbicara halus (lemes) kalau yang diajak bicara lebih tua umurnya dari yang berbicara.

2. Etnisitas orangtua tidak berpengaruh pada penggunaan etika berbahasa Sunda, tetapi penggunaan bahasa Sunda dalam komunikasi di lingkungan keluarga sangat berpengaruh terhadap kualitas Etika berbahasa (undak-usuk basa) sehari-hari.

3. Para nelayan dan pedagang di pantai Pangandaran umumnya sudah mengenal penggunaan etika berbahasa Sunda (undak-usuk basa), meskipun mereka berasal dari daerah lain (jawa) atau orang yang lahir dari keturunan Jawa dan tinggal di lingkungan jawa yang sudah menetap di Pangandaran.

\section{DAFTAR PUSTAKA}

Alwasilah , A. Chaedar. (1986). Sosiologi Bahasa. Bandung : Angkasa.

Halim, Amran (Ed.). (1980). Politik Bahasa Nasional. Jakarta : PN Balai Pustaka. Romaine, S. (1989). Bilingualism. New York : Basic Black Well. 
Rusyana, Y. (1989). Perihal Kedwibahsaan (Bilingualisme). Jakarta : Dirjen Dikti - Depdikbud

Suhendar, H.M.E., Supinah, P., dan Aliah D.,Y. (1997/1998). Pembinaan dan Pengembangan Bahasa Indonesia. Jakarta : Departemen Pendidikan dan Kebudayaan.

Tarigan, Dj., Hidayat, K., dan Sutawijaya, A. (1990) Pendidikan Bahasa Indonesia I : Modul 7-12. Jakarta : Universitas Terbuka.

Tarigan, H.G. (1985). Berbicara sebagai Suatu Keterampilan Berbahasa. Bandung : Angkasa.

Tarigan, H.G. (1994). Menulis Sebagai Suatu Keterampilan Berbahasa. Bandung : Angkasa.

Warsito, Rukmanda. (1984) Transmigrasi : dari Daerah Asal sampai Benturan Budaya di Tempat Pemukiman. Jakarta : CV Rajawali.

Yudibrata, K., Suriamiharja, A., dan Iskandarwassid. (1990). Bagbagan Makena Basa Sunda. Bandung : Rahmat Cijulang

\section{BIODATA PENULIS}

D. Syahruddin adalah dosen pada Universitas Pendidikan Indonesia dpk. UPI Kampus Cibiru Bandung. Penulis menyelesaikan pendidikan pada jenjang magister (S-2) Pendidikan Bahasa Indonesia dari Sekolah Pascasarjana Universitas Pendidikan Indonesia. 